\title{
鉄筋コンクリート長柱の設計 \\ DESIGN OF SLENDER REINFORCED CONCRETE COLUMNS
}

\author{
堺 孝 司* - 角田与史雄** - 能 町 純 雄*** \\ By Koji SAKAI, Yoshio KAKUTA and Sumio NOMACHI
}

\section{1. 緒言}

構造物の設計の目的は，考えられ得るあらゆる荷重状 態に対して, 構造物を構成している部材に十分な強度を もたせることである. そのためには，その構造物の系と しての構造解析を行って, 各構成部材の断面力を算定し なければならない，鉄筋コンクリート $(\mathrm{RC})$ 構造物の 構造解析の方法は, 大きく, 弾性理論に基づく線形解析 と幾何学的非線形性および材料非線形性あるいはそのど ちらか一方を考慮した非線形解析とに分類することがで きよ5．理想的には，各構成部材の断面を仮定し，両非 線形性を考虑した解析を行って，想定される荷重状態に 対して，その構造物が十分な耐力を有するかどらかを検 討することである. しかし，このような解析は逐次計算 となり, その解析手法の煩雑さはもとより，仮定される 断面のあらゆる可能性を考慮するとき, 計算費用の面に おいても，まだ一般的な方法とはいいがたい。

線形解析の 結果に基づいて RC 曲げ部材を設計する 場合の問題の一つは, 柱部材を含む構造において起こ る. 構造系の断面力分布がたわみによって影響されない 場合, 剛性変化のない弾性線形解析による断面力と終局 状態におけるそれとを対応させることはできるが，たわ みと外力とによって付加的な断面力を惹起し，その結果 として，断面の剛性，したがって断面力が逐次変化する よらな構造系においては, もはや弾性理論による線形解 析はその意味をなさない。この付加的な効果は, 一般 に, 二次効果と称されており, この問題の検討は重要で ある.この問題の対処の方法として, (1) 断面力に対す るたわみの影響を剛性変化とともに考慮する方法, (2) 適当に選定された一定剛性を用いて二次弹性解析を行う

* 正会員 工修 北海道大学助手 工学部土木工学科

** 正会員 工博 北海道大学助教授 工学部土木工学科

*** 正会員 工博 北海道大学教授 工学部土木工学科
方法, そして, (3) 解析は弾性理論による 線形解析を行 い，二次効果に関しては別途近似的に考える方法，の 3 つが考えられる. 二次効果の影響を適当な精度で与える ことができれば，第 3 の方法が最も簡単であることはい うまでもない，

以上のようなことを背景に, 本研究では, RC 長柱に ついて, 幾何学的非線形性および材料非線形性を考慮し た解析による数值実験結果から, 回帰解析によって付加 的に発生する二次偏心量に関する定式化を行い，それに 基づいて，設計で考慮すべき二次偏心量の実用式を提案 する.ささらに,これまで行われた単一の柱あるいはフレ 一ム構造に関する実験結果を用いて, 提案した実用設計 式の安全度についての検討を行う。最後に, 設計手順を 示す.

\section{2. 既往の研究と各国設計基準の概要}

\section{(1) 既往の研究}

柱に関する研究は, 古くは, 一端固定他端自由の柱の 限界荷重に関する 1744 年の Euler の研究までさかの ぼることができる ${ }^{1)}$. 構造材料としての鋼の出現は, 細 長い柱, 薄板あるいはその他の複雑な構造形式を可能に し，それに伴って発生する安定問題に関して多くの理論 的および実験的研究がなされてきた.一方，コンクリー トもその品質の安定を得るにつれて, 構造材料として重 要な位置を占めるようになり，必然的に，コンクリート の最大の長所である圧縮強度が大きいという特性を十分 に活用し得る 部材として, 柱は最適な 構造部材となっ た. RC 長柱に関する初期の研究では, Engesser-Kármán 理論の RC への適用が主であったが2),3)，1963 年, Chang らは, 柱のたわみに対する横断面のひびわれの 影響を調べることを目的に，所定の軸力下におけるモー メント・曲率関係を用いる数值積分法を示した ${ }^{4}$. また, 
1964 年には, Pfrang らが拘束を受ける柱に関する数值 解析法を示した ${ }^{5), 6)}$ 。その後も，今日まで，持続荷重あ るいは 2 軸曲げを受ける柱，あるいは柱を含むフレーム 構造に関するものなど, 多くの解析的な研究がなされて

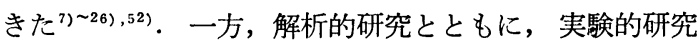
も古くから行われてきたことはいらまでもない.これら については，5．において既往の実験結果として一括す る.

このような多くの実験的および解析的研究の蓄積は， $\mathrm{RC}$ 長柱の設計法の発展に大きく寄与してきた. 以下 に，各国設計基準に採用されている設計法について述心゙ る.

\section{（2）各国設計基準}

前述したように， $\mathrm{RC}$ 長柱の設計は，原則的には，そ の断面耐力との間に整合性を有する合理的な構造解析に 基づいて行われるべきである.しかし，弾性線形解析の ような統一的な見解がまだ確立されていない現在，基準 で与えるべき RC 長柱の設計法としては，その原則的な 考え方とは別に近似的な設計法をも許す必要があろう。

各国設計基準の近似設計法における基本的な考え方は 3 つに大別することができる. 第 1 の方法は，土木学会 の RC 示方書 ${ }^{57)}$ や ACI Building Code ${ }^{58)}$ の解説に述心 られている修正 R法などにみられる低減係数法である. この方法は，RC 長柱に対する最初の設計概念であると 思われるが，実際の挙動との間に不整合が存在する．第 2 の方法は, ACI Building Code の Moment Magnifier Method とよばれる方法である.この方法は, 一定剛性を有する単曲率部材の最大たわみを利用して二 次の曲げモーメントを考慮し， RC 長柱の実際の挙動に 対応させようというものである。この方法の採用は， AISC 基準を意識した結果であった ${ }^{27)}$. 第 3 の方法は, 二次モーメントあるいは二次偏心量を直接与える方法で ある.この方法は，二次的な值を妥当な形で表わすこと ができれば， RC 長柱の実際の挙動を設計法に直接反映 させるといら意味において最も合理的な方法であると いえよう。この方法を採用している基準として，CP 11059), CEB-FIP Model Code ${ }^{61)}$ ，および DIN 104560) を挙げることができる.

上述の 3 つの基準の二次偏心量式で考慮された変数は きわめて少なく，非常に単純な形で表わされている.こ こに，著者らができるだけ多くの影響因子を設計式に含 めようと考えた理由がある.

\section{3. 解 析}

\section{（1）短時荷重に対する解析}

\section{a） 解析上の仮定}

$\mathrm{RC}$ 長柱の横断面形状はさまざまなタイプのものが考 えられるが，ここでは簡単のために，矩形横断面のみを 対象とし，かつ全断面同一寸法であると寸る（図一1). 鉄筋の応力〜ひずみ曲線は, 図一2 に示すように, 引張 および圧縮のいずれに対しても同じ完全弾塑性体とす る、また，コンクリートの応力〜ひずみ曲線は，図一3 に示すような二次放物線と直線の 組合せ曲線を仮定す る.なお，コンクリートの引張に対する抵抗および収縮 の影響は無視する．鉄笳の弾性係数 $E_{s}$ は $2.06 \times 10^{5}$ $\mathrm{MPa}$ を，コンクリートの塑性ひずみおよび終局ひずみ は，その強度とは無関倸に，それぞれ $\varepsilon_{c y}=0.002$ およ び $\varepsilon_{c u}=0.0035$ を仮定する.

b) 解 析 法

本研究で用いた解析法は，幾何学的非線形性を考虑す るためのはり要素を用いた有限要素法による二次弾性解 析と，材料非線形性を考慮するための横断面解析の $2 つ$ の部分からなる繰り返し計算法であり，その基本的な考 えは Jakobsen らによって示された ${ }^{199}$.
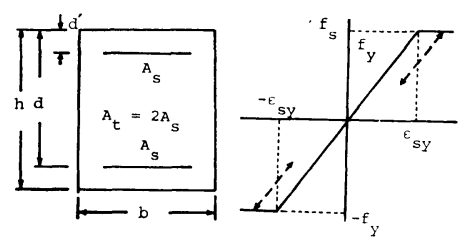

図-1 横断面 図-2 鉄筋の応力〜 ひずみ関係

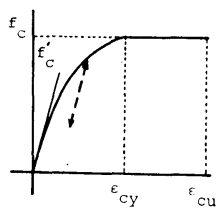

图一3 コンクリート の応力〜ひす み関係

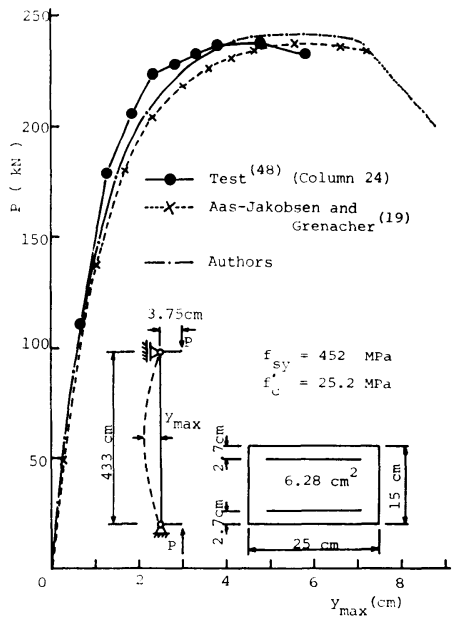

図-4 短時䟠荷の荷重変位曲線 


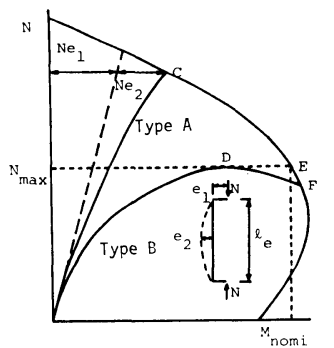

図一5 耐 荷 挙 動 c）耐荷挙動

図一4 は，等偏心荷重を 受ける両端ヒンジの RC 長 柱の耐荷挙動についての Ramu らの実験結果 ${ }^{48)}$, Jakobsen らの計算結果 ${ }^{19)}$, および著者らの計算結果の 比較を示す．著者らの結果 は, Ramu らの実験および Jakobsen らの 計算結果よ り最大荷重で約 $1.6 \%$ 大きくなった．著者らと Jakobsen らの計算結果の差異の原因として, Jakobsen ら が曲率制御のみで行っていること，しかもその増分が非 常に粗いことなどが考えられる.

RC 長柱の変形耐荷挙動は, 横断面形状, 配筋状態, 細長比, 端部拘束度, 作用外力の偏心程度などによって 影響を受けるので複雑であるが, その挙動は 2 つのイ プに分けることができる. 図一5 は, 横断面強度の相互 作用線と柱の耐荷性状とを模式的に示したものである. タイプAは, 点Cでコンクリートが圧壊する場合で, こ の種の破壊は材料破壊と称されている. タイプ $\mathrm{B}$ は, 点 Dで不安定状態となる場合である．この場合にも，最終 的には点 $\mathrm{F}$ で材料破壊するが, 重要なことは, 最大耐力 が断面の終局耐力とならないことである.このような場 合の設計法との関連を考えるとき, 挙動そのものが不安 定現象となるのであるから，そのような挙動に合致した 方法によるのがよいことはいらまでもない.しかしなが ら, 不安定問題として扱う場合, 軸方向はもちろんのこ と荷重レベルごとに変化する剛性をどのように評価して 最大軸力を決定するかといら大きな問題がある. そし て, 何よりも, RC 柱の設計は, 通常, 断面破壊の終局 限界状態でなされているといらことを考えると，これを 不安定問題として扱らのは議論のあるところであろう. そこで, 著者らは,このような場合に対する終局状態と して点Eを考えることにした.

\section{（2）持続荷重に対する解析}

\section{a) 解析上の仮定}

基本的には，(1)，a）での仮定と同じである．新たに 加える仮定について以下に述べる．応力の低減あるいは 再増加の場合, 鉄筋とコンクリートのいずれに対して も，図一2，3 の破線で示すように，応力とひずみの線 形関係を仮定する. ある一定時間持続応力を受けるコン クリートのひずみの総量 $\varepsilon_{t}$ は, 短時ひずみ $\varepsilon_{\mathrm{IN}}$ とクリ ープひずみ $\varepsilon_{\mathrm{CR}}$ との和で表わせるとする. クリープひ ずみは，Rüsch の実験結果 ${ }^{28)}$ を Manuel ら ${ }^{8)}$ が数式 化した次式を用いる.

$$
\begin{aligned}
& \varepsilon_{\mathrm{CR}}=F 1(n)\left(f_{c} / f_{c}{ }^{\prime}\right)^{3}+F 2(n)\left(f_{c} / f_{c}{ }^{\prime}\right)^{2} \\
& \quad+F 3(n)\left(f_{c} / f_{c}{ }^{\prime}\right) \\
& F 1(n)=0.0009\left(0.64 \log _{10} t+0.4\right) \\
& F 2(n)=0.0008\left(0.64 \log _{10} t+0.4\right) \\
& F 3(n)=0.0007\left(0.64 \log _{10} t+0.4\right)
\end{aligned}
$$

ここで, $t$ は持続載荷日数を表わす. また, 上式は, コ ンクリートの 載荷時材令 が 28 日, 養生は, $20^{\circ} \mathrm{C}$ かつ 湿度 $100 \%$ の状態で 7 日間，それ以降は， $20^{\circ} \mathrm{C}$ かつ湿 度 $50 \%$ という条件のもとで導かれたものである. 変動 応力下におけるコンクリートのクリープ挙動に関する扱 いは, “rate of creep” 法による.

\section{b) 解 析 法}

ある荷重レベルまで短時荷重を作用させ，ある期間持 続載荷の後, 再び短時荷重を作用させる場合を考える. 解析法は，(1)，b）と基本的には同じであるが，持続荷 重を受ける場合，持続期間をいくつかの期間に区分し， それぞれの時間区分について解析しなければならない. Manuel らは, 長期間 (25 年) にわたって持続荷重を 受ける場合, 7 日, 9 か月, 25 年の 3 つの時間区分を考 慮すれば十分正確な值が得られることを示した ${ }^{8)}$. 以下， 持続荷重を受ける場合の解析過程について説明する. ず，ある時間増分に対して弾性解析を行い，断面力およ びひずみ分布を算定する. 次に，これらの各横断面にお ける各維ひずみが，コンクリートの全ひずみ量が $\varepsilon_{\mathrm{IN}}+$ $\varepsilon_{\mathrm{CR}}$ であるといら仮定を用いて得られるひずみと一致す るまで, 応力の微調整を行う. 次に, この応力分布より 断面力を算定し，これを弾性解析による断面力と比較し て, 所定の精度に入っていなければ，新しい剛性を仮定 し，上記の過程を繰り返す.この手順を各時間区分ごと に行らのである. 持続載荷後の短時載荷の計算では, ク リープひずみ総量は, 最後まで一定として扱われる.

c) 耐荷 挙動

図一6 は,コンクリート材令 28 日で短時荷重を作用 させた後, 141 日間持続荷重を保ち, その後再び短時荷 重を作用させた両端ヒンジの RC 長柱の 耐荷挙動につ いての Ramu らの実験結果 ${ }^{48)}$, Jakobsen らの計算結 果 ${ }^{19)}$, および著者らの計算結果との比較を示す. 著者ら の計算においては， $t=141$ 日に対するクリープひずみ 量の $1 / 3$ に対応する日数より時間区分を決定した. 実験 值とそれぞれの計算結果は，持続載荷終了の時点におけ る変位が若干異なるが, 最大荷重はよく一致していると いえる. 著者らと Jakobsen らの計算結果において, 持 続載荷終了時における変位の比較的大きな差は, クリ一 プひずみ量の評価の違いによるものであると思われる.

著者らの方法の妥当性について, いま少し検討するこ とにする. 同じくコンクリートの载荷時材令が 28 日で, 持続載荷期間が 6 か月という両端ヒンジの RC 長柱に 


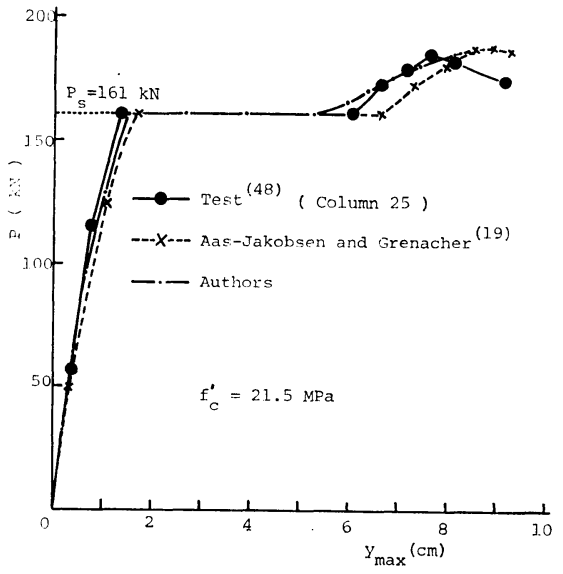

図一6 持続戴荷を含む荷重変位曲線

関する Goyal らの実験結果 ${ }^{15)}$ から，柱の諸元を考慮し て適当に選んだ 6 ケースについて，著者らの計算結果と の比較を示したのが 表一1 である.これら実験結果と の相対的な関倸から, 著者らの方法で十分その最大荷重 をとらえることができると考える.

\section{4. 数值実験および二次偏心量}

\section{(1) 数 值 実験}

上述した解析手法を用いて, RC 長柱の二次モーメン トを評価するために数值実験を行った. 考慮した変数は

1. 断面高さと柱長の比 : $\beta=l / h=10,15,20,25,30$, 35,40

2. 鉄笳比 : $\rho_{t}=A_{t} / b h=0.008,0.021,0.034,0.047$, 0.06

3. 配笳位置 : $r=\left(d-d^{\prime}\right) / h=0.7,0.8,0.9$

4. 作用荷重偏心 : $\delta=e_{1} / h=0.1,0.2,0.3,0.4$

5. コンクリート圧 縮強度 : $f_{c}{ }^{\prime}=19.6,29.4,39.2$ $\mathrm{MPa}$

6. 鉄笳降伏強度 : $f_{y}=235,343,392 \mathrm{MPa}$
であり,これらの組合せの中から，短時載荷の場合につ いて 453 ケース, 持続載荷を含む場合について 480 ケ 一スの合わせて 933 の場合についての計算を行った。 ただし, 持続載荷の場合, ある変数の組合せに対して, 持続荷重の大きさを, それと同じ柱の短時載荷の最大荷 重の $0.2,0.3,0.5$ 倍の 3 種類について計算している ので, 実際の変数組合せはその $1 / 3$ ということになる. また，持続期間は 25 年とした.

数值実験では, 両端ヒンジでかつ外力が等偏心位置に 作用し，そのたわみ形に変曲点を起こさせない柱のみを 扱った.

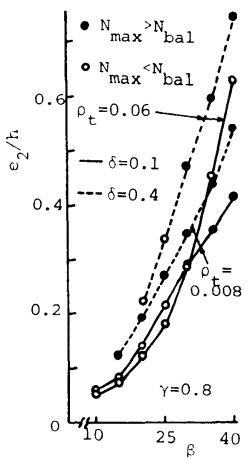

(a)

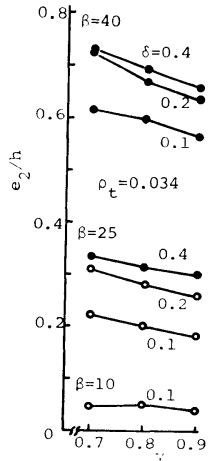

(c)

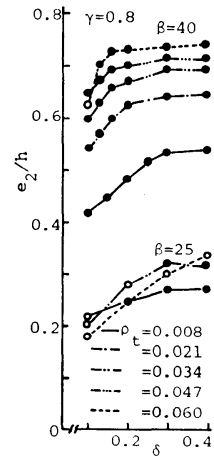

(b)

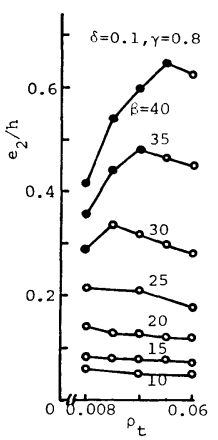

(d)
図-1 短時載荷の場合の $e_{2} / h$ に対する 各変数の 影響 $\left(f_{c}^{\prime}=29.4 \mathrm{MPa}, f_{y}=343 \mathrm{MPa}\right)$

表一1 実験結果 ${ }^{15)}$ と計算結果との比較の例

\begin{tabular}{|c|c|c|c|c|c|c|c|c|c|c|}
\hline \multirow[b]{2}{*}{ 供試体 } & \multicolumn{2}{|c|}{ 短 時 載 荷 } & \multicolumn{2}{|r|}{ 持 } & \multicolumn{3}{|c|}{ 荷 } & \multirow{2}{*}{$\begin{array}{c}\frac{P_{\text {s.cal }}}{P_{\text {cal }}} \\
\text { (a) }\end{array}$} & \multirow{2}{*}{$\begin{array}{c}\frac{P_{s, \exp }}{P_{\text {exp }}} \\
\text { (b) }\end{array}$} & \multirow{2}{*}{$\frac{(\mathrm{b})}{(\mathrm{a})}$} \\
\hline & $\begin{array}{l}\text { 実験最大荷重 } \\
P_{\text {exp }}(\mathrm{kN})\end{array}$ & $\begin{array}{l}\text { 計算最大荷重 } \\
P_{\text {cal }}(\mathrm{kN})\end{array}$ & $\begin{array}{c}\text { 持 続 荷 重 } \\
P_{s}(\mathrm{kN})\end{array}$ & $P_{s} / P_{\mathrm{cal}}$ & $\begin{array}{l}\text { 実験最大荷重 } \\
P_{s, e x p(\mathrm{kN})}\end{array}$ & $\begin{array}{l}\text { 計算最大荷 }{ }^{\text {重 }} \\
P_{s, \mathrm{cal}}(\mathrm{kN})\end{array}$ & $P_{s, \text { exp } /} P_{s, \mathrm{cal}}$ & & & \\
\hline A & $\begin{array}{l}33.14 \\
33.36\end{array}$ & 33.59 & 20.15 & 0.6 & 31.98 & 31.92 & 1.00 & 0.95 & 0.96 & 1.01 \\
\hline B & $\begin{array}{l}33.14 \\
33.36\end{array}$ & 33.59 & 13.44 & 0.4 & 32.29 & 32.56 & 0.99 & 0.97 & 0.97 & 1.00 \\
\hline $\mathbf{K}$ & $\begin{array}{l}46.57 \\
45.59\end{array}$ & 45.63 & 27.38 & 0.6 & 40.88 & 39.25 & 1.04 & 0.86 & 0.89 & 1.03 \\
\hline L & $\begin{array}{l}46.57 \\
45.59\end{array}$ & 45.63 & 18.25 & 0.4 & 43.82 & 42.77 & 1.02 & 0.94 & 0.95 & 1.01 \\
\hline $\mathrm{O}$ & $\begin{array}{l}82.30 \\
92.39\end{array}$ & 80.45 & 48.27 & 0.6 & 89.19 & 69.94 & 1.28 & 0.87 & 1.02 & 1.17 \\
\hline $\mathbf{R}$ & $\begin{array}{l}33.45 \\
31.14\end{array}$ & 31.70 & 19.02 & 0.6 & 24.07 & 26.38 & 0.91 & 0.83 & 0.75 & 0.90 \\
\hline
\end{tabular}




\section{（2）二次偏心量とその形式化}

図一7 9 は, 考慮した各変数の二次偏心量 $e_{2} / h$ に対 する影響の例を示したものである.これらの図では, 最 大軸力がつり合い軸力 $\left(N_{\mathrm{bal}}\right)$ より大きい場合と小さい 場合とを区別して示した. 以後の説明の便宜のために, 前者を CASE A, 後者を CASE B と称する.

まず, 短時荷重についてみると, $\beta$ と $r$ につては, CASE A と CASE B の定性的な傾向に大きな差異は ないといえる.しかし， $\rho_{t}$ についてはまったく異なっ た性状を示している. 次に, $\delta$ の影響についてみれば, CASE A の場合, $\delta$ の増加とともに $e_{2} / h$ はほぼ単調增 加であるが, CASE B の場合, $\delta$ に対する $e_{2} / h$ の増加 率は徐々に小さくなり, 最後にほぼ一定状態とみなせる ような性状を示している.

以上の結果から, 二次偏心量に対して最も大きな影響 のある因子は $\beta$ であり, その他の変数は副次的な影響と みなすことができる. 種々の検討の結果, 最終的な二次 偏心量に関する回帰式として, 最大荷重に対する持続荷 重の比 $P_{s} / P_{s, \max }$ の影響をも含めた次式を考慮した.

$$
\begin{aligned}
\frac{e_{2}}{h}= & \left(\beta+\beta_{1}\right)^{3}\left(\beta_{2}+\beta_{3} \cdot \delta+\beta_{4} \cdot \gamma+\beta_{5} \cdot \rho_{t}\right. \\
& +\beta_{6} \cdot \rho_{t} \frac{f_{y}}{f_{c}^{\prime}}+\beta_{7} \frac{f_{y}}{f_{c}^{\prime}}+\beta_{8} \cdot \rho_{t} \frac{E_{s}}{f_{c^{\prime}}} \\
& \left.+\beta_{9} \frac{P_{s}}{P_{s, \max }}+\beta_{10} \cdot \rho_{t} \frac{P_{s}}{P_{s, \max }}\right)+\beta_{11}
\end{aligned}
$$

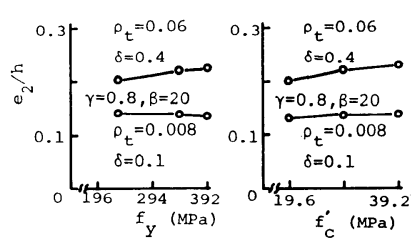

(a)

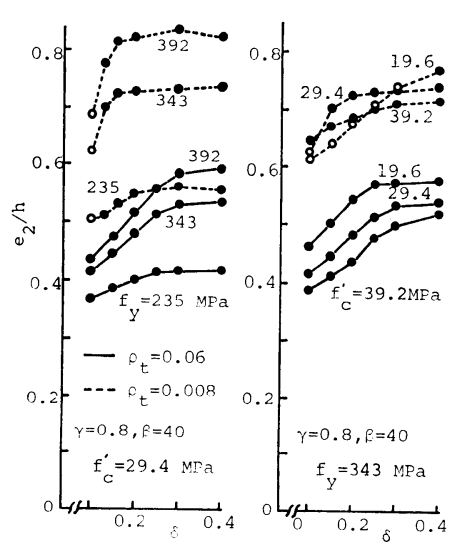

(b)

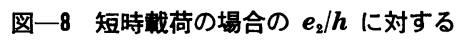
材料強度の影響

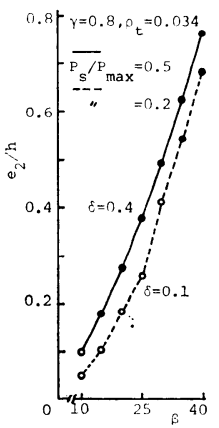

(a)

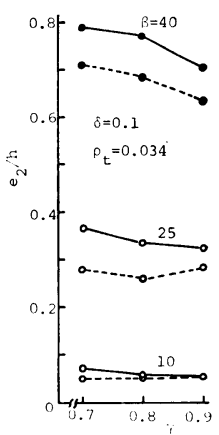

(c)

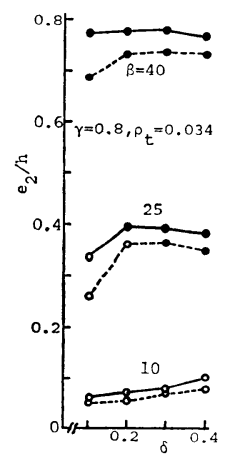

(b)

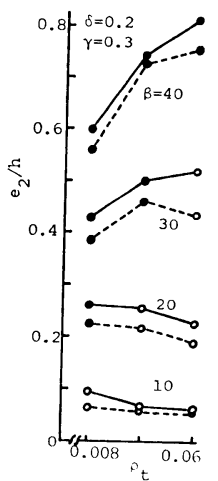

(d)
図一9持䋽载荷を含む場合の $e_{2} / h$ に対する 各変数の影锌

CASE A および CASE B のおのおのの場合に関する 各係数を表一2 に示す. な㧍, CASE A では $\beta_{6}=\beta_{7}=$ $\beta_{8}=0$ とした.

\begin{tabular}{|c|c|c|}
\hline 表-2 & $\begin{array}{l}\text { 回州式の侣 } \\
\text { 数値実験と }\end{array}$ & $\begin{array}{l}\text { 数および } \\
\text { の適合度 }\end{array}$ \\
\hline 係 数 & CASE A & CASE B \\
\hline$\beta_{1}$ & 14.76 & 46.65 \\
\hline$\beta_{2}$ & 5.48 & 0.966 \\
\hline$\beta_{8}$ & 6.44 & 0.313 \\
\hline$\beta_{4}$ & -2.69 & -0.435 \\
\hline$\beta_{5}$ & -1.83 & 8.28 \\
\hline$\beta_{0}$ & - & 1.11 \\
\hline$\beta_{7}$ & - & 0.0176 \\
\hline$\beta_{8}$ & - & -0.00206 \\
\hline$\beta_{0}$ & 5.13 & 0.331 \\
\hline$\beta_{10}$ & -50.1 & -2.36 \\
\hline$\beta_{11}$ & -0.0217 & -0.100 \\
\hline 標準偏差 & 0.1082 & 0.06873 \\
\hline 変動係数 & 0.1074 & 0.06894 \\
\hline $\begin{array}{l}\text { 重相関係 } \\
\text { 数の二莱 }\end{array}$ & 0.9868 & 0.9794 \\
\hline 平均 值 & 1.007 & 0.9970 \\
\hline
\end{tabular}

\section{（3）設計用二次偏心量}

二次偏心量の 回帰式 (1) は, 持続荷重が コンクリー 卜材令 28 日で作用し, 25 年間続くといら 条件 のもとで導かれたもので ある.したがって, 任意 の材令および持続期間に 対しても利用できるよう に, 式 (1) にクリープ 係数 $\varphi$ を導入すること にする. そのために，コ ンクリートの載荷時材令 35 日および 1 年の場合 についての数值実験を補 足的に行い, クリープ係 数に相当する值を算定し た. その結果, クリープ 係数は種々の条件で異な 
り, 載荷時材令 28 日，35 日，1年についてそれぞれ $3.51 \sim 2.31 ， 2.67 \sim 1.50$, および $1.05 \sim 0.66$ の範囲に

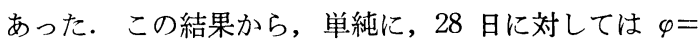
3,1 年に対しては $\varphi=1$ とすることにした. 最終的に は，持続荷重に関係する項に $(\varphi-1) / 2$ を乗じた形で表 わすことにした. これは， $\varphi=1$ のとき持続荷重の影響 を無視することを意味する。

設計用二次偏心量として, CASE A および CASE B の両者とも, 数值実験結果のほほ $5 \%$ が危険側となるよ らにし, さらに, CASE B の場合 $f_{y}=392 \mathrm{MPa}, f_{c}{ }^{\prime}$ $=19.6 \mathrm{MPa}$ とした次式を提案する.

(a) $N_{d}>N_{\text {bal }}$ の場合 (CASE A)

$$
\begin{aligned}
e_{2} / h= & \left(l_{e} / h+16\right)^{3}\left(5.48+6.4 e_{1} / h-2.7 \gamma\right. \\
& \left.-1.8 \rho_{t}+C_{N}\right) \times 10^{-6}-0.02 \ldots \ldots \ldots \\
C_{N}= & 2.5(\varphi-1)\left(1-10 \rho_{t}\right) N_{c} / N_{d}
\end{aligned}
$$

(b) $N_{d} \leqq N_{\text {bal }}$ の場合 (CASE B)

$$
\begin{aligned}
e_{2} / h= & \left(l_{e} / h+48\right)^{3}\left(1.32+0.31 e_{1} / h-0.44 r\right. \\
& \left.+8.9 \rho_{t}+C_{M}\right) \times 10^{-6}-0.1 \cdots \ldots \ldots \ldots \\
C_{M}= & 0.17(\varphi-1)\left(1-7.3 \rho_{t}\right) N_{c} / N_{d}
\end{aligned}
$$

ここで, $l_{e}$ は有効長, $N_{d}$ は設計荷重, $N_{\mathrm{bal}}$ はつり 合い軸力, $N_{c}$ は設計持続荷重を表わす.

\section{5. 設計用二次偏心量の実験結果との比較検討}

\section{(1) 既往の実験}

これまでも， RC 長柱の設計法の妥当性を検討するこ とを目的にデータの集積が行われた ${ }^{16), 29)}$. 本研究でも， 多くの実験結果を用いて上述の設計用二次偏心量の安全 度に関する 検討を行う．採用した実験供試体の数は， Cranston が集積した 381 に，新たに 245 を加えて，総 数が 626 である. その一覧を，供試体の数，柱端拘束

\begin{tabular}{|c|c|c|c|c|c|c|c|c|c|c|c|}
\hline \multirow{2}{*}{ 実 } & \multirow{2}{*}{ 年 } & \multirow{2}{*}{ 供試体数 } & \multicolumn{3}{|c|}{ 柱 の 種 類* } & \multicolumn{3}{|c|}{ 載 } & \multicolumn{3}{|c|}{ 法** } \\
\hline & & & $\mathrm{P}$ & $\mathrm{F}$ & B & $\mathrm{s}$ & $\mathrm{L}$ & L-S & $\mathrm{L}-\mathrm{C}$ & $|\mathrm{L}-\mathrm{C}-\mathrm{S}|$ & $\mathrm{C}-\mathrm{S}$ \\
\hline Baumann $^{30)}$ & 1934 & 43 & 30 & 13 & & 43 & & & & & \\
\hline Thomas $^{31)}$ & 1939 & 14 & 14 & & & 14 & & & & & \\
\hline $\operatorname{Ramb} \phi 11^{32}$ & 1951 & 38 & 38 & & & 38 & & & & & \\
\hline Ernst, Hromadik and Riveland ${ }^{3 s)}$ & 1952 & 8 & 8 & & & 8 & & & & & \\
\hline Gehler and Hütter ${ }^{84)}$ & 1954 & 50 & 50 & & & 50 & & & & & \\
\hline Gaede $e^{35)}$ & 1958 & 16 & 16 & & & 8 & 8 & & & & \\
\hline Kordina $^{86)}$ & 1960 & 4 & 4 & & & 4 & & & & & \\
\hline Aas-Jakobsen ${ }^{37)}$ & 1960 & 20 & 20 & & & 20 & & & & & \\
\hline Saenz and Martin ${ }^{88)}$ & 1963 & 52 & & 52 & & 52 & & & & & \\
\hline Chang and Ferguson") & 1963 & 6 & 6 & & & 6 & & & & & \\
\hline Breen and Ferguson ${ }^{39}$ ) & 1964 & 6 & & 6 & & 5 & & 1 & & & \\
\hline Ramamurthy ${ }^{40)}$ & 1965 & 55 & & & 55 & 55 & & & & & \\
\hline Martin and Olivieri ${ }^{41}$ & 1966 & 8 & 8 & & & 8 & & & & & \\
\hline MacGregor and Barter ${ }^{42)}$ & 1966 & 8 & 4 & 4 & & 8 & & & & & \\
\hline Furlong and Ferguson ${ }^{43}$ & 1966 & 7 & & 7 & & 6 & & 1 & & & \\
\hline Ferguson and Breen ${ }^{44}$ & 1966 & 8 & & 8 & & 7 & 1 & & & & \\
\hline Pannell and Robinson ${ }^{45}$ & 1968 & 16 & 9 & & 7 & 16 & & & & & \\
\hline Green and Breen ${ }^{48}$ & 1969 & 5 & 5 & & & 1 & 4 & & & & \\
\hline $\begin{array}{l}\text { Mehmel, Schwarz, Kasparek and } \\
\text { Makovi }{ }^{(7)}\end{array}$ & 1969 & 16 & 14 & 2 & & 16 & & & & & \\
\hline Breen and Ferguson ${ }^{11}$ & 1969 & 10 & 10 & & & 10 & & & & & \\
\hline $\begin{array}{l}\text { Ramu, Grenacher, Baumann and } \\
\text { Thürlimann }\end{array}$ & 1969 & 37 & 37 & & & 6 & 19 & 12 & & & \\
\hline Cranston and Sturrock ${ }^{49}$ & 1971 & 8 & 3 & & 5 & 8 & & & & & \\
\hline Drysdale and Huggins ${ }^{50}$ & 1971 & 57 & 8 & & 49 & 26 & 16 & 15 & & & \\
\hline Goyal and Jackson ${ }^{15}$, & 1971 & 46 & 46 & & & 26 & & 20 & & & \\
\hline Hellesland and Green ${ }^{51)}$ & 1971 & 6 & 6 & & & & & & & 6 & \\
\hline 平澤52) & 1974 & 55 & 11 & & 44 & 35 & & 10 & 2 & 3 & 5 \\
\hline Kordina $^{58)}$ & 1975 & 12 & 12 & & & & & 12 & & & \\
\hline Blomeier and Breen ${ }^{(4)}$ & 1975 & 3 & & 3 & & 3 & & & & & \\
\hline Green and Hellesland ${ }^{55}$ & 1975 & 8 & 8 & & & 2 & & & 2 & & 4 \\
\hline Gruber and $\mathrm{Menn}^{56)}$ & 1978 & 4 & 4 & & & 4 & & & & & \\
\hline 計 & & 626 & 371 & 95 & 160 & 485 & 48 & 71 & 4 & 9 & 9 \\
\hline
\end{tabular}
条件, および載荷条件を含めて, 表一3 に示す.

\section{（2）実験データ作成上の仮定}

おのおのの実験では，用いた鉄筋やコンクリートの夕 イプはもちろんのこと, 供試体の養生, 載荷時材令, あ るいは実験中の環境条件などさまざまであるが, 煩雑さ

* $\mathrm{P}=$ 端拘束な $L, F=$ 端拘束あり, $\mathrm{B}=$ 二軸曲げ

** $\mathrm{S}=$ 短時荷重, $\mathrm{L}=$ =持続荷重, $\mathrm{C}=$ 繰り返し荷重 


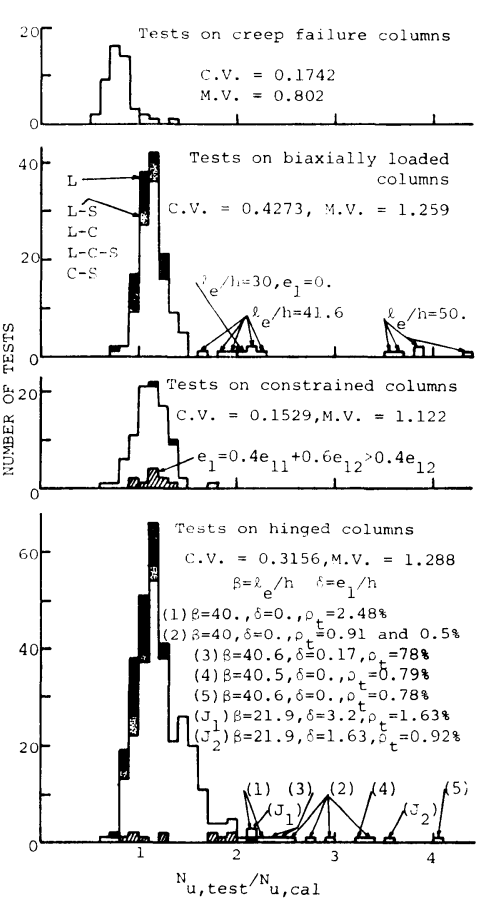

図一10各条件ことの $N_{u, \text { test }} / N_{u, \text { cal }}$ の度数分布図
を避けるため

に,ここでは

以下に述べる

仮定のもとに

統一的な扱い

をした．鉄筋

およびュンク

リートの応力

〜ひずみ関係

は 3. で仮定

したものを用

いる.ただ

し, コンクリ

一トの立方体

強度は, 近似

的に円柱強度

の 1.25 倍で

あるとする。

柱の有効長 $l_{e}$ は, CP 110

の式 $(20) \sim$

(23) による.

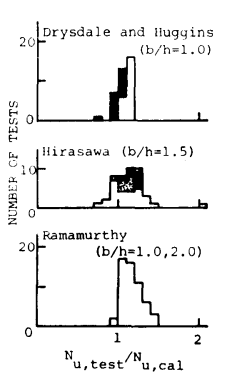

図一11 二軸曲げに関 する著者別の $\boldsymbol{N}_{u, \text { test }} / \boldsymbol{N}_{u, \text { cal }}$ の度数分布図

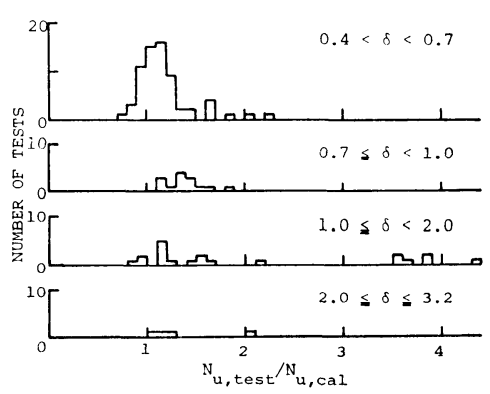

図一12 $8>0.4$ に関する $N_{u, \text { test }} / N_{u, \text { cal }}$ の 度数分布図

また, 二軸曲げの場合, 断面高さ と柱長の比 $l_{e} / h$ は常に $b \geqq h$ の もとで考慮される. 不等偏心の場 合の一次偏心量の評価は, ACI, CP 110, CEB-FIP で採用されて いる等価偏心 $e_{e q}=0.4 e_{11}+0.6$ $e_{12} \geqq 0.4 e_{12}$ で行う.フレーム 構造の場合における柱の一次偏心 量は, 通常の弾性解析より得られ る曲げモーメントと軸力の比より 求める仮想值である.また, クリ ープ係数は, よく知られた $\varphi(t$,

$\left.t_{0}\right)=0.4 \beta_{d}$ $\left(t-t_{0}\right)+\varphi_{f}$ $\left[\beta_{f}(t)-\beta_{f}\right.$ $\left(t_{0}\right)$ ] で評価 することにす る. 環境条件 としての相対 湿度は,すべ ての実験に対 して $40 \%$ と した. 持続載

荷の際考虑した，相対湿度 $50 \%, t_{0}=28$ 日, $t=25$ 年 に対するクリープ係数を上述の式を用いて算定し，それ

を数值実験から

得られるクリー プ倸数（柱軸方 向および横断面 高さ方向で変化 する）と比較検 討した結果, 十 分な一致とはい いがたいがクリ ープ現象の不確 実さを考慮する と, 同一のレベ ルで考慮しても よい範囲である と判断した.

二軸曲げの問 題は, 本研究で は, 近似的に一

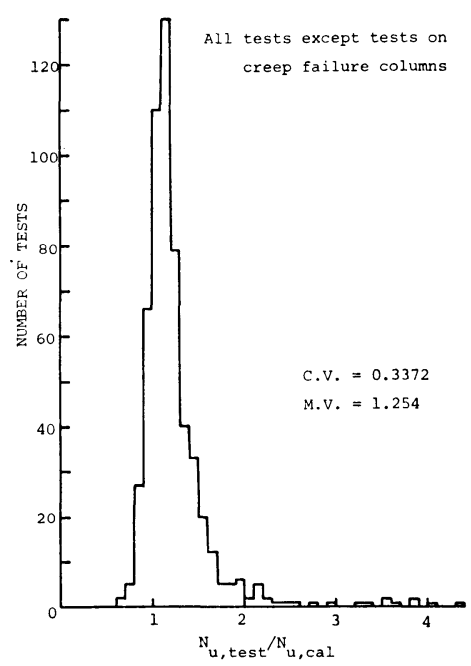

軸曲げとして扱うことにした. すなわち，考慮する曲げ は, 常に弱軸 ( $y$ 軸) まわりとし, 二軸曲げに伴う耐 力低減を等価偏心の導入によって考虑するものである. 種々の検討の結果, 二軸曲げの場合の等価偏心として, 次式を採用することにした $(b \geqq h)$.

$$
\begin{aligned}
& e_{1} / h=e_{X} / h+0.6 \sin \theta \cdot e_{Y} / b \\
& \tan \theta=e_{Y} h / e_{X} b
\end{aligned}
$$

ここで， $e_{Y}$ および $e_{X}$ は，それぞれ弱軸方向およびそ れと直角方向の一次偏心を表わす.

\section{（3）設計式と実験との比較}

図一10 は, 実験を, 端ヒンジの柱, 端拘束の柱, 二 軸曲げの柱, およびクリープ 破壊の柱の 4 つに 分類し て, それぞれの場合に関する実験值 $N_{u, \text { test }}$ と設計式 (2)，(3) による計算值 $N_{\boldsymbol{u} \text {, cal }}$ の比に対する度数分布を 表わす。

クリープ破壊の柱に関する結果は，そのほとんどが危 険側となっている. しかし, 実際の設計において, 柱が クリープ破壊を起こすような高い持続荷重を想定するこ とはまれであり，本論文で述べる設計法の適用範囲外と して扱う.クリープ破壊が予測されるような場合には, それに対応する検討を別に行ら必要がある.

拘束のある柱の結果は, ヒンジの柱に関する結果とほ ぼ同じような $N_{u, \text { test }} / N_{u, \text { cal }}$ の分布形状を示している. このことは, 用いた有効長 $l_{e}$ の妥当性を示すものであ る.

二軸曲げの柱では, $N_{u, \text { test }} / N_{u, \text { cal }}$ がかなり大きな值 となる場合がみられるが，これらはそのほとんどが Sturrock らおよび Pannel らの実験結果であり,それ 
ぞれの $l_{e} / h$ は 50 および $41.6, b / h$ は 4.0 および 1.48 である.図一11にここらの著者以外についての著者 別の度数分布を示す.

端ヒンジの柱に関しても，二軸曲げの場合と同様に， かなり大きな $N_{u, \text { test }} / N_{u, \text { cal }}$ がみられる. そのほとん どが, 大きな $l_{e} / h$, 小さな鉄筋比, かつ一次偏心が 0 の 場合である.このことから，このような場合，提案した 設計式はかなり安全側の結果を与えるといえるかもしれ ない.

持続載荷および繰り返し載荷を含む場合についてもデ 一タの特別な偏りはみられず, 設計用二次偏心量は, こ のような場合にも適用できるものと思われる.

図一10には，不等偏心力を受けた場合に関する結果 を，他の場合と区別して示してある.ヒンジの柱の場合 に, $N_{u, \text { test }} / N_{u, \text { cal }}$ の比較的大きなものがあるが, これ らは, Martin らの実験による結果であり，等価偏心を 用いる必要のなかった他の 2 つの場合も大きな值を示し た、したがって，これらは等価偏心を用いたことによる 結果ではないことが推測される，データの数は少ない が, 不等偏心の場合についても, 等価偏心として $e_{e q}=$ $0.4 e_{11}+0.6 e_{12} \geqq 0.4 e_{12}$ を用いてもよいと思われる.

数值実験では， $\delta$ の範囲として $0.1 〜 0.4$ を考慮した. $\delta>0.4$ の場合に対する適用性を調べるために，実験結 果との比較を示したのが 図一12 である. $\delta$ の各範囲に ついての $N_{u, \text { test }} / N_{u, \text { cal }}$ の分布に顕著な差異はみられ ない. $N_{u, \text { test }} / N_{u, \text { cal }}>2$ の結果に関するものについて はすでに述べたとおりである。したがって，これらの結 果から, 設計用二次偏心量は， $\delta$ が少なくとも 3 程度ま では十分適用できそうである.

図一13 は，クリープ破壊の データを除いた 全データ に関する度数分布を示す. $N_{u, \text { test }} / N_{u, \text { cal }}<1$ のデータ は 100 個ある. $N_{u, \text { test }} / N_{u, \text { cal }}<0.85$ のデータは 16 個であり，全データに占めるこの割合は $3 \%$ 搦である. ちなみに, $N_{\boldsymbol{u}, \text { test }} / N_{\boldsymbol{u}, \mathrm{cal}}<0.9$ のデータは 34 個であ り，全データに占める割合は約 $6 \%$ である. 以上述べ た設計式の安全度の評価のための $N_{u, \text { cal }}$ の算定では, 供試体のコンクリート強度として円柱強度をそのまま用 いた.これは，コンクリート強度に関していえば，設計 式を最も危険な状態で評価したことになる．なぜなら，

表一4 $\boldsymbol{N}_{u \text {,test }} / \boldsymbol{N}_{u, \text { cal } 1}$ に対する各 設計式の適合度

\begin{tabular}{c|c|c|c}
\hline 設 計 式 & データ数 & 変野係数 & 平均估 \\
\hline DIN 1045 & 240 & 0.172 & 1.18 \\
CEB-FIP & 447 & 0.582 & 1.51 \\
CP 110 & 578 & 0.515 & 1.23 \\
& & $(0.493)$ & $(1.27)$ \\
著 者 5 & 578 & 0.337 & 1.25 \\
& & $(0.324)$ & $(1.34)$ \\
\hline
\end{tabular}

通常, 実際のコン クリート強度は円 柱強度より小さい とされているから である。

表一4 は, DIN 1045, CEB-FIP, CP 110，および著
者らの二次偏心に関す る設計式を用いた場合 の $N_{u, \text { test }} / N_{u, \text { cal }}$ に 対する変動係数, 平均 值，およびデータの数 を示す. DIN 1045 の データの数が少ないの は, その適用範囲が狭 いためである. CEBFIPの場合, 用いた二 次偏心量は $e_{2}=l_{e}{ }^{2} / 10$ $\times \phi$ であり, その解説 に従って $\phi=5 \times 10^{-3} / d$ とした.また, CP 110

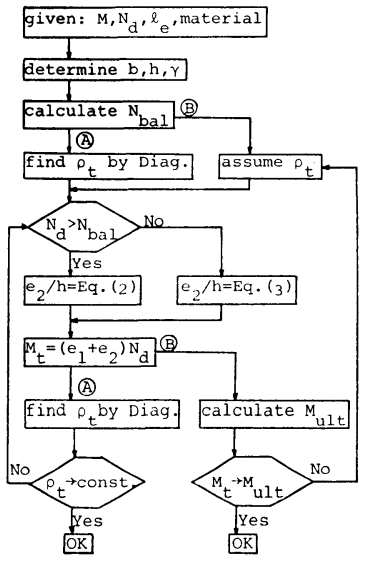

図一14 設計手 順
や著者らよりデータ数が少ないのは, 二軸曲げの場合, $\left|e_{Y_{1}} b / e_{X_{1}} b\right| \leqq 0.2$ 以外についての直接的な $e_{2}$ の評価式 が与えられていないことから，そのようなデータを除外 したためである．CP 110 の結果は，設計終局荷重がつ り合い軸力より大きい場合にその使用が許されている調 整係数 $K_{1}$ を考慮しなかった場合を示す. 括弧の中の值 は, Cranston が行ったように ${ }^{16)}$, 調整係数を考慮し， 供試体のコンクリート強度を 円柱強度の 0.838 倍とし て計算した結果である. 一般に，コンクリート強度を小 さく見積って $N_{u, c a l}$ を算定するということは， $N_{u, \text { test }} /$ $N_{u, \text { cal }}$ の分布が安全側に移動することになる．逆に， $K_{1} \leqq 1$ の考慮は，考慮しない場合より $N_{u, \text { cal }}$ を大き くすることを意味する. 両者の相殺効果により, 平均值 はほとんど変化していない，著者らの括弧の中の結果 は，単に，コンクリート強度を円柱強度の 0.85 倍とし た場合である.この場合， $N_{u, \text { test }} / N_{u, \text { cal }}<0.9$ および $<0.85$ のデータは, それぞれ 12 個および 6 個である.

以上，広範囲にわたる実験データとの比較 検 討の結 果, 提案した設計用二次偏心量は，実用上，十分その使 用に耐え得るものであるといえよう。

\section{6. 設 計 法}

曲げと軸力を受ける RC 長柱の設計手順を 図一14 に 示す. 設計手順は，モーメント〜軸力〜鉄筋比の関係が 図表で用意されている場合と用意されていない場合とで 若干異なったものとなり，図では前者を(A)，後者を(B) としてある．以下，簡単にその概要について述べる.

(1) 断面寸法および配筋位置を決定する.

(2) つり合い軸力 $N_{\mathrm{bal}}$ を算定する.

(3) (A) の場 合, 所定の $M, N_{d}$ より鉄筋比 $\rho_{t}$ を求 める. (B) の場合，まったく任意に $\rho_{t}$ を仮定する.

(4) $N_{\boldsymbol{d}}>N_{\mathrm{bal}}$ の場合は式 (2) で，それ以外は式 
（3）で考慮すべき二次偏心量 $e_{2}$ を算定する.

(5) 二次モーメントを含む全モーメント $M_{t}$ を算定 する.

(6) (A)の場合， $M_{t}$ と $N$ に対して新たに $\rho_{t}$ を求め る.この手順を $\rho_{t}$ が一定となるまで繰り返す. (B)の場 合， $N_{d}$ および所定の断面諸元に対する終局曲げモーメ ント $M_{\mathrm{u} 1 \mathrm{t}}$ を算定する．原則的には， $M_{t}<M_{\mathrm{ult}}$ であ ればよい。

\section{7. 結 語}

本研究は, RC 長柱に関する一つの近似設計法を提示 することを目的に行われた. そのために，まず，短時載 荷の場合および持続載荷を含む場合についての RC 長 柱の解析を逐次計算で行う方法を示し, 数值実験を行っ た. 次に, その数值実験結果による回帰式に基づいて, 設計用二次偏心量なる設計式を提案した. さらに, 提案 した設計式の妥当性を検討するために, これまでに行わ れた 626 個の実験結果との比較を行った. その結果, 提案した設計式は, 有効長, 不等偏心, および二軸曲げ の場合の等価偏心が適当に評価されると, 端ヒンジの柱 はもちろん, 端拘束の柱および二軸曲げの柱に関しても 実用上十分利用できることが示された. また，この提 案設計式は, 同じ設計概念を有する, 適用範囲の狭い DIN 1045 を除いて, CP 110 および CEB-FIP の設計 式と比べて格段によい精度であることが示された.

本研究は, 文部省科学研究費 (昭和 57 年度奨励研究 (A), No. 57750396) によって行ったものである. なお， 数值計算には北海道大学大型計算機センターの HITAC M-200 H を使用した。

\section{参考 献}

1) Timoshenko, S.P. and M.J. Gere : Theory of Elastic Stability, McGraw-Hill Book Company, Inc., 2nd Edition, p. 46.

2) Broms, B. and I.M. Viest : Ultimate Strength of Hinged Columns, Transaction, ASCE, SYMPOSIUM, VOL. 126, pp. 306 339, 1961.

3) Broms, B. and I.M. Viest : Ultimate Strength Analysis of Restrained Columns, Transaction, ASCE, SYMPOSIUM, VOL. 126, pp. 348 366, 1961.

4) Chang, W.F. and P.M. Ferguson : Long Hinged Reinforced Concrete Columns, ACI Journal, Proceedings Vol. 60, No. 1, pp. 1 25, January 1963.

5) Pfrang, E.O. and C.P. Siess : Predicting Structural Behavior Analytically, Proceedings of ASCE, ST 5, pp. 99 111, October 1964.

6) Pfrang, E.O. and C.P. Siess : Behavior of Restrained Reinforced Concrete Columns, Proceedings of ASCE, ST 5, pp. 113 136, October 1964.

7) Schwarz, H. and K.H. Kasparek : Ein Beitrag zur Klärung des Tragverhaltens exzentrisch beanspruchter Stahlbetonstützen, Der Bauingenieur, Heft 3, pp. 84
$90,1967$.

8) Manuel, R.F. and J.G. MacGregor : Analysis of Restrained Reinforced Concrete Columns under Sustained Load, ACI Journal, pp. 12 23, January 1967.

9) Bažant, Z.P. : Creep Stability and Buckling Strength of Concrete Columns, Magazine of Concrete Research, Vol. 20, No. 63, pp. 85 94, June 1968.

10) Farah, A. and M.W. Huggins : Analysis of Reinforced Concrete Columns Subjected to Longitudinal Load and Biaxial Bending, ACI Journal, pp. 569 575, July 1969 .

11) Breen, J.E. and P.M. Ferguson : Long Cantilever Columns Subject to Lateral Forces, ACI Journal, pp. 884 893, November 1969.

12) Pagay, S.N., P.M. Ferguson and J.E. Breen : Importance of Beam Properties on Concrete Column Behavior, ACI Journal, pp. 808 815, October 1970.

13) Quast, U. : Traglastnachweis für Stahlbetonstützen nach der Theorie II. Ordnung mit Hilfe einer vereinfachten Moment-Krummungsbeziehung, Beton- und Stahlbetonbau, pp. 256 271, 11/1970.

14) Ferguson, P.M., H. Okamura and S. Pagay : Computer Study of Long Columns in Frames, ACI Journal, pp. 955 958, December 1970.

15) Goyal, B.B. and N. Jackson : Slender Concrete Columns under Sustained Load, Proceedings of ASCE, ST 11, pp. 2729 2750, November 1971.

16) Cranston, W.B. : Analysis and Design of Reinforced Concrete Columns, Cement and Concrete Association, Research Report 20, p. 54, 1972.

17) Lazaro, A.L. and R. Richards : Full-Range Analysis of Concrete Frames, Proceedings of ASCE, ST 8, pp. 1761 1783, August 1973.

18) Hays, C.O. and H. Matlock : Nonlinear Discrete Element Analysis of Frames, Proceedings of ASCE, ST 10, pp. 2011 2030, October 1973.

19) Aas-Jakobsen, K. and M. Grenacher : Analysis of Slender Reinforced Concrete Frames, Bericht Nr. 50, Institut für Baustatik ETH Zürich, p. 17, Märt 1974.

20) Hage, S.E. and J.G. MacGregor : Stability Analysis and Design of Concrete Frames, Proceedings of ASCE, ST 10, pp. 1953 1977, October 1977.

21) Grelat, A. : Comportment Non Linéaire et Stabilité des Ossatures en Béton Armé, ANNALES, N³66, pp. 105 126, Novembre 1978.

22) Bažant, Z.P. and T. Tsubaki : Nonlinear Creep Buckling of Reinforced Concrete Columns, Proceedings of ASCE, ST 11, pp. 2235 2257, November 1980.

23) Hellesland, J. and A.C. Scordelis : Analysis of R.C. Bridge Columns under Imposed Deformations, IABSE COLLOQUIUM, DELFT 1981, pp. 545 559.

24) Virdi, K.S. : Biaxially Loaded Slender Reinforced Concrete Columns, IABSE COLLOQUIUM, DELFT 1981, pp. $449 \sim 461$.

25) Al-Noury, S.I. and W.F. Chen : Finite Segment Method for Biaxially Loaded RC Columns, Proceedings of ASCE, ST 4, pp. 780 799, April 1982.

26) Mari, A., J. Murcia and A. Aguado: Second Order Analysis of Reinforced Concrete Frames, CEB BULLETIN D'INFORMATION, No153, pp. 183 196, Avril 1982.

27) MacGregor, J.G., J.E. Breen and E.O. Pfrang: 
Design of Slender Concrete Columns, ACI Journal, pp. 6〜28, January 1970 .

28) Rüsch, H. : Researches Toward a General Flexural Theory for Structural Concrete, ACI Journal, pp. 1 $\sim 28$, July 1960 .

29) CEB-FIP, Manual of Buckling and Instability, Longman Inc., New York, p. 60, 1978.

30) Baumann, O. : Unacquired paper, data of which were obtained in reference (16)

31) Thomas, F.G. : Unacquired paper, data of which were obtained in reference (16)

32) Ramb $\phi 11$, B.J. : Unacquired paper, data of which were obtained in reference (16)

33) Ernst, G.C., J.J. Hromadik and A.R. Riveland : Unacquired paper, data of which were obtained in reference (16).

34) Gehler, W. and A. Hütter : Knickversuche mit Stahlbetonsäulen, Deutscher Ausschuss für Stahlbeton, Heft 113, pp. 1 56, 1954.

35) Gaede, K. : Knicken von Stahlbetonstäben unter Kurzund Langzeitbelastung, Deutscher Ausschuss für Stahlbeton, Heft 129, 1958.

36) Kordina, K. : Unpublished work, data of which were obtained in reference (16).

37) Aas-Jakobsen, A. : Unpublished work, data of which were obtained in reference (16).

38) Saenz, L.P. and I. Martin : Test of Reinforced Concrete Columns with High Slenderness Ratio, ACI Journal, pp. 589 616, May 1963.

39) Breen, J.E. and P.M. Ferguson : The Restrained Long Concrete Column as a Part of 'a Rectangular Frame, ACI Journal, pp. 563 588, May 1964.

40) Ramamurthy, L.N. : Investigation of the Ultimate Strength of Square and Rectangular Columns under Biaxially Eccentric Loads, SYMPOSIUM ON REINFORCED CONCRETE COLUMNS, DETROIT, ACI SP-13, pp. 263 298, 1966.

41) Martin, I. and E. Olivieri : Test of Reinforced Concrete Columns Bent in Double Curvature, SYMPOSIUM ON REINFORCED CONCRETE COLUMNS, DETROIT, ACI SP-13, pp. 121 138, 1966.

42) MacGregor, J.G. and S.L. Barter : Long Eccentrically Loaded Concrete Columns Bent in Double Curvature, SYMPOSIUM ON REINFORCED CONCRETE COLUMNS, DETROIT, ACI SP-13, pp. 139 156, 1966.

43) Furlong, R.W. and P.M. Ferguson : Tests of Frames with Columns in Single Curvature, SYMPOSIUM ON REINFORCED CONCRETE COLUMNS, DETROIT, ACI SP-13, pp. 55 73, 1966.
44) Ferguson, P.M. and J.E. Breen : Investigation of the Long Concrete Column in a Frame Subject to Lateral Loads, SYMPOSIUM ON REINFORCED CONCRETE COLUMNS, DETROIT, ACI SP-13, pp. 75 114, 1966.

45) Pannell, F.N. and J.L. Robinson : Slender Reinforced Concrete Columns with Biaxial Eccentricity of Loading, Magazine of Concrete Research, Vol. 20, No. 65, pp. 195 204, December 1968.

46) Green, R. and J.E. Breen : Eccentrically Loaded Concrete Column under Sustained Load, ACI Journal, pp. 866 874, November 1969.

47) Mehmel, A., H. Schwarz, K.H. Kasparek and J. Makovi : Tragverhalten ausmittig beanspruchter Stahlbetondruckglieder, Deutscher Ausschuss für Stahlbeton, Heft 204, p. 54, 1969.

48) Ramu, P., M. Grenacher, M. Baumann and B. Thürlimann: Versuche an gelenkig gelagerten Stahlbetonstützen unter Dauerlast, Bericht Nr. 6418-1, Institut für Baustatik ETH Zürich, p. 86, 1969.

49) Cranston, W.B. and R.D. Sturrock: Unacquired paper, data of which were obtained in reference (16)

50) Drysdale, R.G. and M.W. Huggins : Sustained Biaxial Load on Slender Concrete Columns, Proceedings of ASCE, ST 5, pp. 1423 1442, May 1971.

51) Hellesland, J. and R. Green : Sustained and Cyclic Loadings of Concrete Columns, Proceedings of ASCE, ST 4, pp. 1113 1128, April 1971.

52）平澤征夫 : 二軸曲げを受ける 鉄笳コンクリート柱部材の 力学的挙動に関する 基礎的研究, 京都大学学位論文, p. $173,1974$.

53) Kordina, K. : Langzeitversuche an Stahlbetonstützen, Deutscher Ausschuss für Stahlbeton, Heft 250, p. 36, 1975.

54) Blomeier, G.A. and J.E. Breen : Effect of Yielding of Restraints on Slender Concrete Columns with Sidesway Prevented, ACI SP 50-2, pp. 41 65, 1975.

55) Green, R. and J. Hellesland : Repeated Loading Tests of Reinforced Concrete Columns, ACI SP 50-3, pp. 67 91, 1975.

56) Gruber, L. and C. Menn : Berechnung und Bemessung schlanker Stahlbetonstützen, Bericht Nr. 84, Institut für Baustatik ETH Zürich, p. 23, 1978.

57）土木学会, 無筋および 鉄筋コンクリート標準示方書, 昭 和 55 年版.

58) ACI $318-77$, Building Code Requirements for Reinforced Concrete, 1977.

59) BSI CP 110, The Structural Use of Concrete, 1972.

60) DIN 1045, 1978.

61) CEB-FIP Model Code for Concrete Structures, 1978.

(1983.3.9 - 受付) 